\title{
Male Domination in Inheritance and Development of Gim Embroidery in Surakarta, Indonesia
}

\author{
Yuhri Inang Prihatina \\ Department of Home Economics \\ Universitas Negeri Surabaya \\ Surabaya, Indonesia \\ yuhriinang@unesa.ac.id
}

\begin{abstract}
Gim embroidery is a crucial ornament both in Ngayogyakarta Hadiningrat palace and in Surakarta Hadiningrat palace. Surakarta's embroiderers are often found from three generations, male parents to his sons and nephews, and or grandsons and grandnephews. Gim embroidery is only used during special occasions such as, important and sacred ceremonies. Therefore, it is not a sideline job, it is done through tirakat (fasting), and only men with less domestic responsibilities can do this.
\end{abstract}

Keywords-Gim embroiderers, Gim Embroidery, male domination, crucial ornament

\section{INTRODUCTION}

Male and female's role differences are often linked to the community perception on biological differences that have been passed down for generations. Biologically, male is considered as powerful and female is considered as powerless. Roles distribution between male and female are mostly distributed by physical strength, women are often given roles that are considered as soft and housekeeping works while men are often assigned to do roles that are considered as jobs that need physical strength or public works. This is also commonly found in handcrafters across Indonesia, males most often dominates handicrafts works that needs strength and power such as wood carving, metal carving, etc. Meanwhile, for delicate crafting are often done by women, such as weaving, batik, and also making embroidery.

Gim embroidery made from gold metallic or silk metallic threads. It is used as outfit ornaments during the great ceremony and on panji (flag or emblems) in Ngayogyakarta Hadiningrat palace. The gold ornaments of gim embroidery have high aesthetic value, meticulous, and detail. Gim threads are embroidered into velvet fabrics, exclusive fabrics that are only used by the members of the royal family or those who held important positions and are economically settled or the rich families. During the seventeenth and eighteenth centuries, women's role as textile producers were replaced by the increasing import volume from India. During that time, the fabric has started to have different meaning. The shirt and blouse fabrics imported by the European, Chinese and Moslems merchants have no sacred meaning. The clothes made from these cheap fabrics are used daily, meanwhile silk and rich velvet embroidered with gold and silver threads were used by the riches to show their wealth off [1].

There are two well-known types of gim threads, the fine and coarse threads. The classic gold ornaments are tailored into the palace outfits using the fine gim embroidery. Technically, it needs high precision and meticulously done. It has spiral-like structure, flexible, and fragile toward pulling, which become the main techniques in embroidery. In addition, it also uses filler from cardboard and rope to make the embroidery signage.

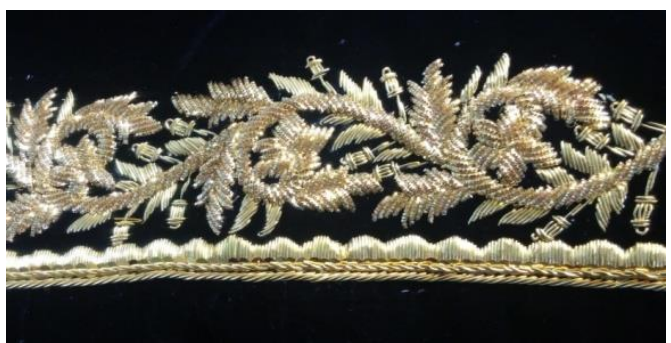

Fig.1. Lung-lungan motif of gim embroidery using the combination of fine and coarse threads. [2]

Investigation on the gim embroidery artisans is conducted around the Surakarta palace. This is to map out the productive its areas. Generally the artisans tend to live in clusters; they conduct activities and reflections to understand important things in life [3]. This is different from artist that works individually; artisans tend to live in groups. During the palace ruling time, artisans are often residing in cluster within the outskirt of the capital city. Nowadays, it is till common to find skin craftsmen, batik craftsmen, and silver craftsmen that live together in certain areas.

The first gim embroider artist found in Joyosuran of Surakarta, Central Java. With his wife and his daughter, he accepts embroidery orders from one of the Java bridal store in Surakarta. The second embroider artist found in Sukoharjo, Central Java. With his wife and his father, he accepts gim embroidery orders from various cities, such as, Yogyakarta, Semarang, Surabaya, Jakarta, and even from Malaysia.

An interesting thing about the existence of these gim embroiderers is that this embroidery skill is mastered by male 
and is passed down from the male lineage in the family. Both the first gim embroider artist and the second gim embroider artist are male. They determine the motives, designs, price, and orders for the embroidery, meanwhile, their wives assist in embroidery. This is different from other craft arts, in which, embroidery crafts skill are generally mastered by women. Crafts arts are done and managed based on gender that is by observing the role division for men and women. Not every people is allowed to be involved in traditional activities, there are art products that related to women, such as, earthenware, embroidery, cooking equipment, and food processing. On the other hand, there are also a number of crafting activities dominated by male such as, transportation vehicle, hunting equipment, fishing equipment, housing and weapons [4].

This article is a collection of empirical data on the inheritance and development of gim embroidery in Surakarta residence that constitutes from Surakarta city, district of Sukoharjo, district of Sragen, and district of Klaten. The data are obtained through observation, interview, and document study. The observation and interview data are obtained from three informants. The informant one is the first gim embroider artist from Surakarta, informant two is the second gim embroider artist from Sukoharjo, and Surakarta Palace makeup artist, and informant three is Surakarta Hadiningrat Palace Bridal Makeup. In addition, the data on gim embroidery are gathered from documents available in museum, artifacts, and other library references related to gim embroidery and its existence in Java.

The focus of this research is why the gim craftsmen are dominated by male and how this crafting skill is passed down and developed today in Surakarta.

\section{RESLT AND DISCUSSION}

Gim embroidery is one of the important ornaments in Ngayogyakarta Hadiningrat palace. This is evident in the artifacts found at the Yogyakarta palace museum, where the gim embroidery is found in the sinewoko (the sultan's throne) at the main hall. In this museum also, an artifact of supitan outfit of GRM Dorodjatun (the childhood name of the Sultan HB IX) embroidered with gim thread in fading old gold color. Even though, these artifacts have been there since the time of HB VIII or in 1921 - 1939, this embroidery is still beautiful and elegant.

Gim embroidery has been part of the Indonesian handicrafts before the XVIII century, however, the artifacts that still can be easily found is the artifacts from the era of Sultan Hamengku Bowono VIII. This is suspected to be the beginning of the golden era for gim embroidery in Java especially in Ngayogyakarta Hadiningrat Sultanate. The same observation is also conducted at the museum of Surakarta palace, however, other than the documents like photos of the gim embroidery used by those in high rank positions at the Surakarta Hadiningrat such, as photos of GPH Kusumo Yudo, GPH Dipo Kusumo, GPH Benowo, GPH Cahya Ningrat, GPH Suryo Mataram, and KGPH Hangabehi, no artifacts are found in this palace on gim embroidery. GPH stands for Gusti Pangeran Harya, is the title given to the adult sons of the Susuhunan (Sultan). With this title, a son of the Susuhunan is considered as "Junior Prince" and is usually involved in palace business with certain responsibilities. Meanwhile, KGPH , which stands for Kanjeng Gusti Pangeran Harya is a title given to the sons of Susuhunan that are not only considered senior in age, but also have excellent performance. This title is a "Senior Prince" title that generally puts the holder of the title in high ranks position within the sultanate.

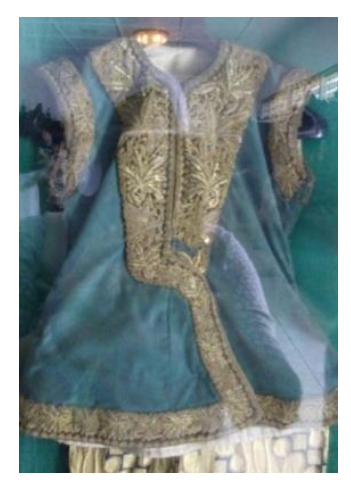

Fig.2. Supitan (circumcision) outfit of GRM Dorodjatun (childhood name of Sultan HB IX)

Based on the interview with Surakarta Hadiningrat Palace Bridal Makeup, on the 24 November 2015, it was revealed that the gim embroidery had been developed since the Pakubuwono V era, where Mataram had used the gim [5]. Especially for the official bridal outfit established during the Mataram era as the bridal outfit out the Ngayogyakarta Hadiningrat Sultanate. On the other hand, the bridal outfit of Surakarta Hadiningrat Sultanate had some traditional alterations on the outfit; however, it still used the same ornaments of golden gim embroidery. Gim embroidery is originated from India but brought in to Indonesia by Dutch and Chinese through politics and trades. Both of the fabrics and the gim threads were imported from India. In the seventeenth and eighteenth centuries, women's role as textile producer was replaced by increasing import volume of fabrics from India. At the same time, the meaning of fabrics has started to shifts. The shirt and blouse fabrics imported by the European, Chinese and Moslems traders have no sacred meaning. The clothes made from these cheap fabrics are used daily, meanwhile, silk and velvet are decorated with gold and silk threads used by the palace people as means to show off their wealth [1].

The usage of outfit within the sultanate has certain rules to differentiate the usage and in what occasion the outfit is used. The usage of the outfit or rasukan within the wall of the palace [6]. They are differentiate into rasukan padintenan or daily usage, rasukan sutera cekak (short kebaya) for small ceremony or to go out of the palace, and rasukan panjang (long kebaya) for great ceremonies or sacred ceremonies that consists of rasukan panjang peniti setunggal (long kebaya with single pin/ brooch), rasukan panjang peniti susun (long kebaya with tier pin/ brooch) and rasukan panjang bludiran (long kebaya with embroidery). The fabrics for these long kebaya are also made from velvet, silk, and brocade.

There are regulations not only about who are able to use and during what ceremony the outfits are used, but also the 
ornaments that decorated the outfits also have certain regulation. The width of the ornaments and the technique to create the ornaments are detailed used as the signature of one's status within the sultanates, both in Ngayogyakarta Hadiningrat sultanate and in Surakarta Hadiningrat Sultanate. The width of the ornaments in sikepan bludiran (outfit with embroidery) shows the status of the bearer, for instance, a lurah prince and Hangabehi prince, the older son of the garwa ampeyan (concubine wife), uses the $15 \mathrm{~cm}$ width of sikepan bludiran with gold ornaments (narrower than that of the crown prince), even though the ornaments are both started from the back below the neck. For a dalem son (prince) with the title of Gusti Pangeran, the width of the gold embroidery is narrower than the lurah prince, and is started above the shoulders (without the golden threads in the back part). The other sons from the queen wear sikepan bludiran outfits with the ornaments that are narrower than the sikepan bludiran worn by the dalem sons with the title of Gusti Pangeran Harya. A 10 $\mathrm{cm}$ ornaments show that the bearer is a son born from concubine wife. Condronegoro agrees with Pigeaud that the small differences on the outfits, such as, the width of the ornaments in an outfit or the width of line in a dodot fabric will show different status of the bearers [6].

Bludiran can be defined as gold or silver threads embroidery located in an outfit or kamus (belt), in which, the embroiderers and the bridal makeup called them as gim embroidery. Wikipedia called them gold work embroidery that is the embroidery arts using the metal threads. There are several types of metal threads, and it is known that the gim thread has the same characteristics like those of bullion or purl thread. Bullion means gold or silver, purl means knitting or it can also mean as the thread with very long structure, has some core or hollow, and can be pulled. The usage of this type of threads can be cut long or short and implemented like when creating beads.

The investigation on gim embroidery is initially done at the area surrounding the Surakarta Hadiningrat sultanate, however, there is no center of gim embroiderers found. The investigation is carried out into the center of bridal outfit market in Beringharjo market in Yogyakarta due to gim embroidery is currently widely used in Javanese wedding outfit both in Yogyakarta style and Surakarta style. Information on the existence of gim embroidery is initially hard to found, not all the shops sell the gim embroidery due to the high price. One information found that the center of gim embroiderers can be found in Klaten area at the Penggung, Jatinom, Kunden, Klaten. The investigation to this area bears no result on the gim embroiderers. Instead, it is found that Klaten is the center for bridal outfit creations using easier and cheaper ornaments like beads embroidery compared to gim embroidery.

The first information on gim embroiderers was found in the area of Joyosuran Surakarta. He had been working on gim embroidery since 1974. Currently, he worked on gim embroidery together with his wife and his daughter. He worked in a famous Javanese bridal shop in Surakarta. He called this shop as factory. In order to produce kebaya, beskap (suit), kuluk (hat), he could bring them home. However, to work on gim embroidery for flags or emblems it had to be done in factory. In addition, he also received orders to work in gim embroidery from his nephew (the second embroiderer).

The first embroiderer was given gim embroidery skill from his brother-in-law or his wife's older brother. Since 1974, he had been helping his father in gim embroidery. He had three siblings, one male and two females and all of them were gim embroiderers. One of them is the wife of the first embroiderer. The first embroiderer was inherited the gim embroidery skill from his grand father-in-law. His grandfather was one of the gim embroiderers at Surakarta Hadiningrat Sultanate. This gim embroidery skill was passed down the first embroiderer and the second embroiderer.
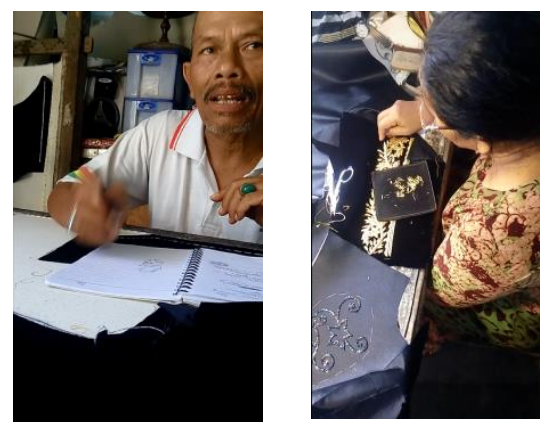

Fig. 3. The first embroiderer is drawing a motif and his wife is embroidering [7] Observation and interview on April 17, 2016

The second embroiderers is the informant two, is the nephew of the first embroiderer. With his wife, his father and four other embroiderers receive orders on gim embroidery independently at Grogol, Sukoharjo.

The second embroiderer consumers came from Yogyakarta, Semarang, Surabaya, Jakarta, Kalimantan and even from Malaysia. He made many types of gim embroidery both traditional and modification. In general, the second embroiderer's work was more diverse with modern touch. This is evident in the usage of combination of soft gim, coarse gim, and beads to give fuller and richer impression. Meanwhile, the orders were also varied from dance outfit, modified kebaya, various kinds of beskap, and flags. Wider market and variation of gim motives were possible because the second embroiderer was familiar with internet information technology such as, Google and WhatsApp. WhatsApp application has enable communication and minimizes the mismatch of the orders. During the interview and observation, the second embroiderer receives several orders through whatsApp, in which, the customers call and sent image through whatsApp. His then used this as notes of the order date and the detail of the orders. All orders, who works on what, when to work on that orders, what motives, and other details are determined by the second embroiderer, meanwhile, the gim embroidery are done by his wife, his father, and his employees. 

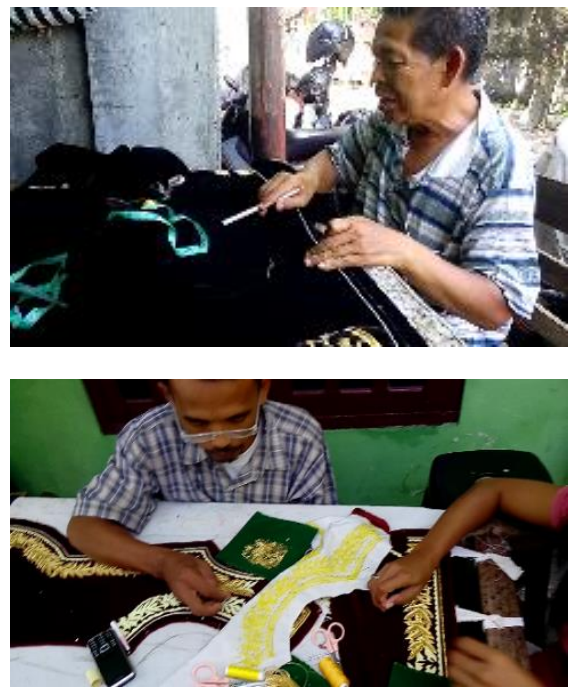

Fig.4. Embroiderer at the second embroiderer [7] Observation and interview on June 23, 2016

The first embroiderer and the second embroiderer said almost similar things, where, several people had come and learnt to do gim embroidery but then they went back to their respected houses and received orders independently. That is why at the beginning the both embroiderers were reluctant to give information related to gim embroidery. Generally, the embroiderers in Solo and Sukoharjo were less open to strangers (non-family) who wanted to learn gim embroidery meanwhile, teaching gim embroidery to the next generations like children and nephews is also hard because they generally choose to work in factories or work as shop keepers or do catering works.

Below is the chart of gim embroidery inheritance in Surakarta and Sukoharjo

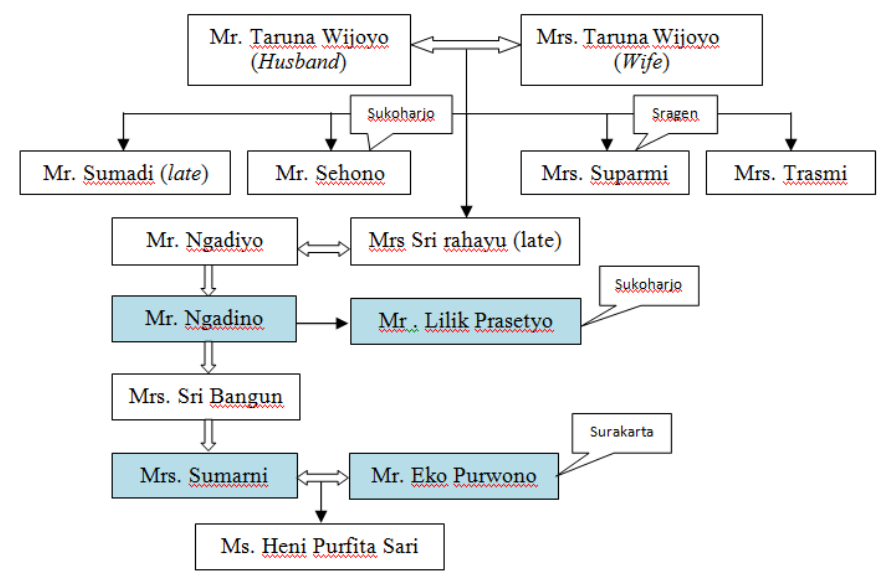

Fig.5. chart of gim embroidery inheritance in Surakarta and Sukoharjo

Notes:

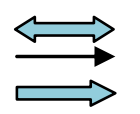

Marital Relationship

Lineage Relationship

Kinship Relationship
There are facts that gim embroidery is a male-dominated skill and passed down to sons and nephews. This is unique than general crafts skill or embroidery skill that are dominated by female or activities for unmarried girls or activities during the time when their husbands are out at works. in North Sumatera, embroidery skill has to be mastered by all women before they got married, and in Gorontalo embroidery is activity of secluded girls before they get married, or wives activity to produce a handicraft when their husband is out at the sea or out at field, farming [8].

On the above chart, it is evident that the gim embroidery is taught by Mr. Taruno Wijoyo to his five children, two males and three females. Four of them are gim embroiderers. Mr. Taruno also taught gim embroidery to his son-in-law, Mr. Ngadiyo. Mr. Ngadiyo then taught the gim embroidery to his three siblings, two females and one male, Mr. Ngadino. Mr. Ngadiyo also taught his brother in Mr. Eko Purwono (the first embroiderer). Mr. Eko passed down the skill to his daughter, Ms. Heni Purfita Sari. Meanwhile, Mr. Ngadino passed down the skill to his son, Mr. Lilik (the second embroiderer). Currently, both the first embroiderer and the second embroiderer play important role in implementing the gim embroidery business. Their respected wives only assist them.

The first embroiderer said that male has been dominating the embroidery job within the sultanate. Gim embroidery is a difficult and meticulous job and cannot be done carelessly, even, he said, when he was still embroidering within the sultanate, the first embroiderer and other embroiderers had to fast in order to create beautiful embroidery, because the result would be used by important people in the palace. He had tried to switch profession during the early trend of modern kebaya, he left gim embroidery due to lack of orders. But after several months, he switched back to embroidery because he had no other skill. Embroidering has been part of him and his family life

In the same tone, Surakarta Hadiningrat Palace bridal makeup also said that several crafts are specifically used for important ceremonies within the palace including embroidery and makeup. At the old times, men do these two things. These muticulous things have to be done wholeheartedly, and usually, they have to do tirakat/fasting before doing the job. Women have many housekeeping such as, cooking, taking care of the children, hence, they cannot wholeheartedly able to do these jobs. During the menstrual time, women are not allowed to do embroidery for the outfit that would be used for great ceremony as well as for sacred ceremony.

Data on the development of gim embroidery are found in the gim embroidery made by the second embroiderer, meanwhile, the gim embroidery made by the first embroiderer are mostly following the pattern of gim embroidery made for palace outfit and the emblems of the palace. He has also made some development on the motive of the gim embroidery, but most of them are still following the pattern of the palace such as, lung-lungan, kembang duren, manggaran, pari-parian and side patterns that consist of blenggi, berji and untu walang patterns. 
The second embroiderer is also familiar with internet, hence the marketing of gim embroidery are wider up to the kebaya couture designer like Anne Avantie and Popy Karim are also using his products. His said that if the design of the motives created by the second embroiderer would not be repeated on other gim embroidery, therefore, he does not allow others to take pictures. He develops the motives with the assistance of his father. He receives orders not only for outfit but also for flags, kuluk, sandals, and other products that the customer desires. The development of gim motives is not only evident on the motive, but also on the combination of soft and coarse gim threads, and usage of fuller beads, and combination of Yogyakarta and Surakarta bridal outfit styles that produces a new style. For instance, it is evident in the removal of adheg-adheg and additional of tabor motive on the Surakarta bridal outfit style. This idea appears because the bridal makeup can use this kebaya/ outfit for two styles of brides either Solo brides or paes ageng jangan menir style.

\section{CONCLUSION}

During the old time, the gim embroiderers are dominated by males. This phenomenon is still found up to the third generations of the first embroiderer. The daughter of the first embroiderer is also an embroiderer; however, she solely works as embroiderer. The different thing is evident in the second embroiderer that plays important role in marketing, motive decision, setting the price of the embroidery as well as determining other important things related to gim embroidery.
Gim embroidery development goes hand in hand with the current trends and the needs of the customers. The clothes designers create new designs, bridal makeup's are in need of outfit that can be mixed and matched, the palaces are also in need of preserving the ancient motives, dance costumes and others are made based on orders. In these cases, both the first embroiderer and the second embroiderer play important roles in development of gim embroidery to balance the tradition and the current trends/modification.

\section{REFERENCES}

[1] Nordholt, Hnek Schulte, 2005. Outward Appearances Trend, Identitas, Kepentingan, Yogyakarta: LKIS

[2] Informan 1 (57 years old), the first gim embroiderer in Joyosuran, Surakarta

[3] Gustami, SP. 2007, Butir-Butir Mutiara Estetika Timur Ide Dasar Penciptaan Seni Kriya Indonesia, Yogyakarta: Prasista

[4] Suhersono, Hery. 2011. Mengenal Lebih Dalam Bordir Lukis Transformasi Seni Kriya ke Seni Lukis, Jakarta: Dian Rakyat

[5] Informan 3 (60 years old), Surakarta Hadiningrat Palace Bridal Makeup.

[6] Condronegoro, Mari. 2010, Memahami Busana Adat Kraton Yogyakarta Warisan Penuh Makna, Yogyakarta: Yayasan Pustaka Nusatama

[7] Informan 2 (40 years old), the second gim embroiderer in Grogol Sukoharjo

[8] Wacik, Triesna Jero. Adikriya Sulam Indonesia Indonesian Embroidery Heritage. Jakarta: Yayasan Sulam Indonesia 